NBER WORKING PAPER SERIES

\title{
FLUCTUATIONS IN WEEKLY HOURS AND TOTAL HOURS WORKED OVER THE PAST 90 YEARS AND THE IMPORTANCE OF CHANGES IN FEDERAL POLICY TOWARD JOB SHARING
}

\author{
Todd Neumann \\ Jason Taylor \\ Price Fishback \\ Working Paper 18816 \\ http://www.nber.org/papers/w18816 \\ NATIONAL BUREAU OF ECONOMIC RESEARCH \\ 1050 Massachusetts Avenue \\ Cambridge, MA 02138 \\ February 2013
}

We owe thanks to Dan Hamermesh and Claudia Goldin for their encouragement. National Science Foundation Grant No. SES-1061927 provided funding for some of the research. The paper does not reflect the opinion of the National Science Foundation in any way. The views expressed herein are those of the authors and do not necessarily reflect the views of the National Bureau of Economic Research.

NBER working papers are circulated for discussion and comment purposes. They have not been peerreviewed or been subject to the review by the NBER Board of Directors that accompanies official NBER publications.

(C) 2013 by Todd Neumann, Jason Taylor, and Price Fishback. All rights reserved. Short sections of text, not to exceed two paragraphs, may be quoted without explicit permission provided that full credit, including $\odot$ notice, is given to the source. 
Fluctuations in Weekly Hours and Total Hours Worked Over the Past 90 Years and the Importance of Changes in Federal Policy Toward Job Sharing Todd Neumann, Jason Taylor, and Price Fishback NBER Working Paper No. 18816

February 2013

JEL No. N12

\begin{abstract}
During the Great Depression of 1930s, changes in the workweek drove a larger portion of changes in total labor input than in other decades. Work-sharing policies appear to be responsible. Hoover created various work-sharing committees lead by key industrialists, which pushed for shorter workweeks and Roosevelt's President's Reemployment Agreement called for sharp cuts in weekly hours. The hope was to spread available work amongst more people. While between 50 and 90 percent of declines in labor input were accommodated by falling hours during these periods, in recent decades employers have primarily relied on layoffs to achieve the same end. During the Great Depression of 1930s, changes in the workweek drove a larger portion of changes in total labor input than in other decades. Work-sharing policies appear to be responsible. Hoover created various work-sharing committees lead by key industrialists, which pushed for shorter workweeks and Roosevelt's President's Reemployment Agreement called for sharp cuts in weekly hours. The hope was to spread available work amongst more people. While between 50 and 90 percent of declines in labor input were accommodated by falling hours during these periods, in recent decades employers have primarily relied on layoffs to achieve the same end.
\end{abstract}

Todd Neumann

Department of Economics

University of Arizona

401 McClelland Hall

Tuscon, AZ 85721

and NBER

tcn@u.arizona.edu

Jason Taylor

Central Michigan University

321 Sloan Hall

Mount Pleasant, MI 48859

taylo2je@cmich.edu
Price Fishback

Department of Economics

University of Arizona

Tucson, AZ 85721

and NBER

pfishback@eller.arizona.edu 
The recent Financial Crisis and Great Recession has generated renewed interest in the Great Depression and particularly the New Deal, as people seek answers about the sources of recovery from a serious downturn. Studies of Depression-era labor markets have focused heavily on downward stickiness of wages because unemployment rose above 20 percent for four years and total hours of employment dropped more and recovered less than the number employed (Bernanke 1983; Cole and Ohanian 1999). High wages are often cited as causing the drops in employment and hours, but it is important to recognize that weekly hours and wages are part of an overall employment package simultaneously set in labor markets. Benjamin Bernanke (1983) recognized this in the analysis that underlay his seminal study of monthly data on employment, hours, and earnings in manufacturing during the Great Depression and in work with Powell (1986) on the post-war era until the early 1980s.

During both the Great Depression and the Great Recession total hours worked dropped dramatically and then remained well below long term trends during the recovery. However, the contributions to changes in total hours of changes in the length of the workweek varied dramatically between the two time periods and over the course of the century. The Median Weekly Hours Share (WHS) in Table 1 uses monthly data from establishment surveys of hours and employment to show the percentage that changes in hours worked per week contributed to changes in total hours worked per week over three-month periods. For each decade, the WHS is calculated for all periods and during periods when total hours rose and periods when they fell. The results show striking changes across the decades. During the 1930s the WHS shows that changes in weekly hours accounted for around half of all changes in total hours worked during both upswings and downswings. During upswings in the post-war era the WHS remained stable at about 25 percent between 1950 and 1980 before rising dramatically to 38 percent in the 1980 s 
and ultimately to 64 percent in the 2000s. This rise has sparked extensive discussions about jobless recoveries since the early 1990s. ${ }^{1}$ During post-war downswings the WHS swung between 31 and 43 percent between 1950 and 1980 and then declined over the next 3 decades to 27 percent in the 1980 s and ultimately to 15 percent by the 2000 s, as layoffs increasingly dominated weekly hours reductions as the means of reducing labor inputs.

Effective analysis of the differences in the role of weekly hours across time periods requires a deep understanding of the labor market institutions and government policies across eras. Our focus is on the 1930s, when the unusual pattern for the WHS for the 1930s was driven in part by a series of emergency policies followed by the federal government in response to moribund labor markets. Some of the patterns in the late 1930 s were created by the introduction of long run policies that established the basis for labor market institutions in later eras. Most recent work on the 1930s has focused on high-wage policies coming through jawboning by President Herbert Hoover in the early 1930s, code negotiations under the National Recovery Administration (NRA), and strengthened unionization under the National Labor Relations Act (NLRA). ${ }^{2}$ We emphasize that high wages were only one part of a policy package that tightly interwove them with reductions in weekly hours and increases in employment. None of these pieces can be treated as isolated from and/or exogenous to the others. Further, we place strong emphasis on several key changes in the policy environment that have been largely glossed over in most prior studies, including the President's Reemployment Agreements beginning in August 1933, and the very weak enforcement of the NLRA until the Supreme Court found it

\footnotetext{
${ }^{1}$ For example, see Gordon and Baily (1993) and Koenders and Rogerson (2005).

${ }^{2}$ See Cole and Ohanian (2004), Ohanian (2009), Eggertsson (2008, 2012) for Dynamic Structural General Equilibrium Models based on high-wage policy. However, see Hanes and James (2012) and Rose (2010) for challenges to the high-wage emphasis.
} 
constitutional in April 1937. These key policy changes are associated with quite striking changes in weekly hours, employment, and hourly earnings.

\section{Changes in the WHS for Manufacturing Over the Last 90 Years}

The role played by changes in weekly hours in changes in total labor inputs has typically been shown by comparing the variances of total hours, weekly hours, and total employment using a time series filter to clear out seasonal fluctuation and long run trends. We chose the WHS approach without seasonal or cyclical adjustment because we wanted to show the data as the policy makers were seeing it, particularly in the 1930s. Further, we wanted to show changes over time in the asymmetry in the WHS during upswings and downswings in hours. Responses to seasonality are unlikely to be the source of the differences in Table 1 because when we calculated the WHS with 12-month changes, the comparisons were similar in magnitude.

The size of the contribution of changes in weekly hours to changes in total labor input was starkly different during the 1930s and the 2000s when compared with other decades. Bernanke and Powell (1986) had noted differences in the behavior of weekly hours between the 1923-1940 and the 1950-1982 periods. The patterns of the WHS in Table 1 also show differences between the two periods as well as some additional variation within the interwar period. During upswings, the WHS in Table 1 shows that the typical contribution of rising weekly hours to the rise in total hours rose from 32 percent in the 1920 s to 45 percent of the increases during the 1930s and then fell back to 27 percent in the 1950s, 1960s, and 1970s. During downswings the changes in the WHS show that reductions in weekly hours contributed 35 percent of the total hours reductions in the 1920s. The percentage rose sharply to 51 percent 
in the 1930s and then dropped back to between 31 and 43 percent of the reductions between 1950 and 1980.

The WHS figures suggest that employers used changes in hours about as much as layoffs, hiring, and firing to change labor inputs during the 1930s. In the 1920s, 1950s, 1960s, and 1970s, adjustments in weekly hours played a much smaller role. Bernanke and Powell (1986, 594-5) attributed the greater stability of post-war hours to greater postwar importance of unions, which may have preferred layoffs of junior workers to a general reduction of hours, and the advent of unemployment insurance, which provided unemployment benefits to fully unemployed workers but not to workers on short time. But this can only be a part of the answer. Most of the difference between the interwar and postwar period arises from the high WHS in the 1930s, while the differences in the WHS between the 1920s and the 1950-1980 period are much smaller. Given that unions were weak and that there was no unemployment insurance in the 1920s, greater unionization and access to unemployment insurance can only partially explain the interwar and post-war differences. A careful look at the policy moves and the harshness of the Great Depression is needed in order to explain the unusual behavior of WHS during $f$ the 1930s.

The WHS measure also reveals a striking change in the role played by hours after 1980 that has led analysts to talk of jobless recoveries and heavy reliance on layoffs. ${ }^{3}$ Increasing talk of jobless recoveries has been driven by rises in the WHS during upswings in hours worked. The share of increases in total hours due to increases in weekly hours has risen sharply each decade from 23 percent in the 1970s to the Depression Era level of 46 percent in the 1990s to a very high 64 percent in the 2000s. Meanwhile, employers appear to have been relying increasingly on

\footnotetext{
${ }^{3}$ On jobless recoveries, see Baily and Gordon (1993), Hamermesh (1993), and Koenders and Rogerson (2005, 555). On the greater use of layoffs see Rayn and Simonelli $(2007,4)$
} 
layoffs and firings rather than reductions in hours worked to reduce labor inputs in manufacturing. The decline in the WHS during downswings since the 1970s shows that the contribution of reductions in weekly hours to reductions in total hours declined from 31 percent in the 1970 s to a low of 15 percent.

\section{Work-sharing Policies during the 1930s}

During the 1920s the average manufacturing work week in most years was close to 48 hours with drops to around 45 hours in the 1921 recession and 47 hours in 1924. After October 1929 average weekly hours shown in Table 2 dropped sharply and stayed below 41 for the remainder of the 1930s. Given the cyclicality of weekly hours, there is no doubt that a significant share of the changes in weekly hours during the 1930s were driven by the size of the Depression. Import the WHS ratio from the 1920s into the 1930s and roughly one-third of the upswings and down-swings in total hours might have been explained by cyclical conditions. Yet, the WHS for the 1930s shows that the actual contribution of changes in weekly hours to the ups and downs in total hours worked was roughly 50 percent.

As shown in Table 2, there were significant changes in the contributions of changes in weekly hours during periods defined by various policy regimes during the 1930s. The WHS in Table 2 is calculated with disaggregated data for 11 manufacturing sectors, so that each observation used to calculate the median is an industry-month. The disaggregated WHSs for the 1920s in Table 2 are very similar to the aggregated WHSs for the 1920s in Table 1. Many but not all of the 11 industries follow similar paths over the period. 


\section{II.a. The Hoover Years}

A share of the differences between the 1930s and other decades can be attributed to the various work-sharing policy regimes pressed by the Hoover and Roosevelt administrations, and even some major industrialists, to help workers survive in an economic emergency. In his memoirs, Hoover $(1953,54-57)$ stated that the labor policies he proposed to industrialists in the early 1930s called for employers to look after the relief of their own workers, maintain employment by work-sharing with weekly hours cuts, and insure that each worker's weekly purchasing power was not cut too drastically by maintaining hourly wages or allowing them to decline only with the cost-of-living. He referred to these work-sharing policies as a type of “indirect relief” for unemployment—contrasting it with "direct relief” whereby funds are provided by some charitable or government action.

The Roosevelt administration followed suit with its policies toward industry and work relief. The President's Reemployment Agreements (PRA) and the NRA codes were explicitly designed with these goals in mind. Meanwhile, work relief under the Federal Emergency Relief Administration (FERA) from 1933 to 1935 was explicitly designed to limit hours of work for recipients so that relief could be provided to more families to reach a minimum consumption standard. In some cities where FERA budgets were overwhelmed, hours and benefits were cut so that more families could at least some help. Under the Works Progress Administration work relief, monthly hours were also limited so that more families would benefit. Unions also pressed for work-sharing by cutting weekly hours but they tried to add a requirement that weekly wages not be cut, a policy that no one else supported.

Hoover's efforts to promote the work-sharing policy began on November 21, 1929, less than one month after the stock market crash, when President Hoover invited several leading 
industrialists to the White House. Hoover asked them to spread "available work...among all employees by temporarily shortening the work-week of individuals" and to maintain wage rates (Rose 2010; Hoover, 54-7).” Following the President's lead, in May 1930, the Railway Employees Department of the American Federation of Labor (AFL) urged a 40-hour workweek as a way to reduce unemployment (Bernstein 1969, 476). The AFL's Executive Council likewise endorsed reductions in work hours as a way to alleviate unemployment at the union's October 1930 convention. Shortly after Standard Oil of New Jersey went to a 40 hour workweek while Kellogg Company adopted an even more radical six-hour day (Hunnicut 1996).

Building upon this momentum, in October of 1930, Hoover created the President's Emergency Committee for Employment (PECE). Consistent with Hoover's general approach to the Depression, the committee encouraged local responsibility and voluntary cooperation from employers with respect to solutions to the employment problem. Shorter workweeks were strongly encouraged by PECE so as to keep workers off relief rolls. US Steel was touted by PECE as a prime example of work-sharing's benefits. Myron C. Taylor, head of US Steel's Finance Committee, went on the radio on behalf of PECE to announce that in December of 1930 the company was operating at only 38 percent of capacity, but it had as many employees as it did in December 1929 thanks to a reduction in the average workweek from 46.2 to 34.4 hours (Bernstein 1969, 306). PECE published pamphlets providing suggestions for how companies could cut hours and optimally time shorter shifts to promote maximum efficiency. Many companies followed suit including American Telephone and Telegraph, Bethlehem Steel, Du Pont, General Electric, General Motors, International Harvester, and Westinghouse. Indeed, the average workweek in manufacturing fell from 44.5 hours in June 1930 to 32.8 hours in June 1932. Some of this drop would certainly have occurred anyway with the faltering economy, but 
the anecdotal evidence presented above suggests that at least some of the 26 percent drop in the workweek was caused by Hoover's work-sharing policies. Over the same 24 months, the number of workers employed in manufacturing fell 32 percent from 7.56 million to 5.10 million, but total labor input (number of employees * average workweek) fell an astounding 50.3 percent from 337 million hours worked to 167 million hours worked per week (see also Figure 1).

Meanwhile, the WHS, as shown in Table 2, rose dramatically relative to the 1920 s. During Hoover's jawboning period through August 1932, the contributions of declines in weekly in hours to declines in total hours rose to 52 percent. In the few periods and industries when total hours rose, employers relied even more on expansions in weekly hours, as the WHS jumped to 80 percent. Had it not been for work-sharing, whether caused by Hoover's policy efforts or by natural agreements between workers and firms to cut workweeks, the unemployment problem in the early 1930s would have been far worse.

In August 1932 Hoover called another conference of industrial leaders to Washington in which he encouraged still more work-sharing via cuts to the workweek. Additionally, Hoover created a share-the-work committee headed by Standard Oil of New Jersey President Walter C. Teagle. The Teagle Committee, with its slogan "Job Security by Job Sharing," further encouraged companies to cut workweeks, and again provided models of how such measures could be accomplished. In early 1933, a survey by the Commerce Department suggested that 80 percent of the nation's employers had adopted some form of work-sharing and that one quarter of those Americans employed owed their situation to this policy (Bernstein, 1969, 479).

Why did so many industrial leaders appear to have followed Hoover's suggestions for work sharing? One contributor may have been that the industrialists agreed with Walter Teague, President of Standard Oil of New Jersey, who used the analogy of famine in advocating work 
sharing. "If there is but a limited amount of food, no one would suggest feeding two-thirds of the distressed people and letting the other third starve. The available food is rationed. That is what we are now doing with work, because there is a partial famine in work" (Weinberg and Weinberg, 1968, p. 247). ${ }^{4}$

Another may have been fears that if they did not follow suit, the Hoover administration might shift federal policy in favor of collective bargaining. During the World War I emergency the federal government had actively promoted collective bargaining over the protests of many industries. After the federal government withdrew its control of large parts of the economy, labor strife followed as employers and workers sought to work out the new rules of bargaining. The end result was that union membership and strike activity waned and the figures in the early 1930s matched post-war lows. Given the nadir of unionization at that time, it does not seem likely that employers feared strikes or unions much. However, the employers might well have feared that an irritated Hoover and Congress would respond to the Depression emergency with new federal labor policy. Hoover $(1953,54-57)$ emphasized that he wanted to prevent lockouts and strikes that would add to the turmoil in his meetings with industrialist. Hoover eventually supported expanded opportunities for collective bargaining by signing the Davis-Bacon Act in March 1931 and the Norris-LaGuardia Act in March 1932.

\section{II.b. Union Pressure for Reduced Hours During the Interregnum}

After Roosevelt's electoral victory in November 1932, labor unions, who had long pushed for shorter workweeks in the US, saw an opening to accomplish not just Hoover's push for firms" "voluntary compliance" in shortening the workweek, but legislative action. During the AFL's annual convention, three weeks after the election, President William Green proposed a six

\footnotetext{
${ }^{4}$ See Baily (1976) and Ohanian (2009) for models of how firms use hours cuts in recessions and job sharing.
} 
hour per day, five-day week, claiming it would have a dramatic positive effect on the unemployment problem. Three weeks after the AFL convention, Senator Hugo Black of Alabama introduced a 30 hour per week bill and in April 1933, the bill passed the Senate.

Himmelberg (1976) notes that many in the Roosevelt Administration felt the 30-hour week was too extreme. Needing to put forth an alternative, the Administration drafted the National Industrial Recovery Act (NIRA). Under the NIRA industries would create "codes of fair competition." To gain government approval, the codes had to contain workweek reductions, with 35 hours being the general guidepost, although hours could vary by industry, city population, and job description. While the NIRA was passed on June 16, 1933, the process of drafting codes of fair competition was slow.

\section{II.c. The President's Reemployment Agreements}

To speed the labor provisions of the act into effect, Roosevelt created the President's Reemployment Agreement (PRA) which began on August 1, 1933. Roosevelt pressed firms to expand employment under the act and asked them to sign a "blanket" agreement to pay minimum hourly wages of 40 cents per hour, raise wages for higher paid workers, cap the workweek at 35 hours, and allow workers to bargain collectively. Roosevelt provided incentives for the firms to sign the agreements through a massive public relations campaign. Firms that signed the agreement were listed on Honor Rolls at post offices and often in newspapers, and were given posters and the right to display the Blue Eagle symbol of the NRA. Roosevelt's Fireside Chats included exhortations for people to support the firms that signed the PRA. In late August of 1933 the NRA sent out 1.5 million volunteers to go door-to-door and obtain 20 million signatures to Statements of Cooperation pledging "cooperate in the reemployment" and support 
and patronize firms that displayed the Blue Eagle. Compliance with the PRA's wage and hours provisions was extremely high (Taylor 2011).

The PRA was associated with a sharp reversal in a prior rise in weekly hours. When industrial production had rebounded sharply between March and July of 1933 in Figure 1, weekly hours had surged to 42.9 hours per week. After the PRA campaign, weekly hours immediately plunged and reached a low of 33.8 in November of 1933. The PRA timing also matched a sharp change in hourly earnings. Real hourly earnings in manufacturing in Figure 1 had bottomed out around May and June of 1933, and then rose sharply over the next three months. Although the number employed in manufacturing continued to rise after the PRAs were signed, the drop in weekly hours was enough that total hours worked fell.

The PRAs were largely in effect from August to December of 1933 when many industries replaced them with NRA codes. One of the most striking features of this period is what happened to the WHS. In contrast to all other periods we have measured, the WHS was negative for industries that were expanding work hours during this five-month span. Weekly hours actually fell when total hours worked were rising, working against the expansion of total hours by a negative 23 percent. In the periods when industries expanded total hours in the PRA time frame, the drop in weekly hours accounted for 89 percent of the expansion in total hours.

The PRAs were the classic example of a package of high wages, job-sharing, and maintenance of employment. Even though they were voluntary, they received much more of a boost than the job-sharing, high wage jawboning by Hoover because of the massive public relations campaign launched by the Roosevelt administration. Further, the PRAs were signed by many nonmanufacturing firms and the changes seen in manufacturing were also seen in mining, 
trade, and nearly every sector except utilities (see Figures in Appendix II). Prior to that time only bond sales had received such promotion during the World War I emergency (Taylor 2011).

\section{II.d. The NRA Codes and the NLRA Before the Court Declared It Constitutional}

The NRA codes were negotiated between employers, workers, and consumers, but the employers typically held the upper hand. Figure 1 for manufacturing industries shows that during the NRA period, hourly earnings rose slightly, while weekly hours were centered around a 35-36 hour level with fluctuations around that level that help drive similar fluctuations in total hours. During that time, the WSH in Table 2 shows that roughly 40 percent of the swings in total hours were contributed by swings in weekly hour in both upswings and downswings. The median WSH's were only slightly higher than those seen in the 1920s.

On May 27, 1935, the Supreme Court's Schechter decision ruled the NIRA and all its component parts unconstitutional. Companies were thus freed from legal obligations to their codes, although there is plenty of evidence that enforcement of the codes had already diminished (Taylor and Klein, 2008). On July 5 President Roosevelt signed the National Labor Relations Act, giving workers the right to collective bargain with their employers if a majority of workers demanded it. Contemporaries describe enormous uncertainty among employers and workers as to whether the Act would survive a test of its constitutionality. Two lower courts had ruled against enforcement of the Act in the Jones \& Loughlin Steel Corporation test case and Roosevelt's court-packing scheme had met extensive opposition. The effects of the passage of the Act seem small, as several measures of strike activity in 1935 and 1936 were well below their levels for 1933 and 1934. Leo Troy's measures of union membership show little change 
between 1934 and 1936, although BLS measures show an increase in union membership of about 25 percent (Rosenbloom 2005, 336-7, 354-5).

In either case the effect of the elimination of the NRA and the introduction of the NLRA are not readily detectible in the labor market data in Figure 1 and Table 2. During a phase of strong recovery in industrial production, weekly hours, total hours worked, and hourly earnings all follow relatively smooth paths with a slightly positive trend from May 1935 through March 1937. The WHS measures in Table 2 are roughly the same for the NRA and NLRA period before constitutionality was affirmed. The WHS in both periods differed drastically from the WHS in the PRA period and still remained somewhat higher than they had in the 1920s.

\section{II.e. A Constitutional National Labor Relations Act}

The changes were far more dramatic when the NLRA was affirmed by the Supreme Court on April 12, 1937 in National Labor Relations Board v. Jones \& Laughlin Steel Corporation, 301 U.S. 1. The effect on strike and union activity was immediate. The number of workers in union recognition strikes nearly quadrupled, from 202,118 and 272,013 in 1935 and 1936 to 941,802 in $1937 .^{5}$ Likewise, annual data on union membership support the notion that 1937 was a key turning point. Estimates from Freeman (1998, p. 289) show that union membership spiked from 3.85 million in 1936 to 6.76 million and 7.76 million respectively in 1937 and $1938 .{ }^{6}$ Additionally these two years saw a surge in sit-down strikes, before the National Labor Relations Board and courts ruled them to be illegal.

\footnotetext{
${ }^{5}$ Recognition strike data are from the US Department of Labor, Bureau of Labor Statistics, Monthly Labor Review, May 1936-May 1940.

${ }^{6}$ Union density data from the BLS and from Troy show a similar pattern (Rosenbloom 2006).
} 
Drops in total hours in Figure 1 started immediately. Some of the drop was likely due to the sudden surge in strike activity, however it is important to note that weekly hours dropped as well. Both series began falling before the sharp drop in industrial production associated with the 1937-1938 recession. Real hourly earnings in Figure 1 had begun to surge a few months before the decision, but surged even more rapidly after the decision. They soon leveled off later in the year, despite sharp drops in output, employment, and hours. The one area where the NLRA decision does not seem to have affected things much was in the WHS measures in Table 2, which were very similar before and after the court decision.

The next change in federal policy was the passage of the Fair Labor Standards Act in June of 1938 , however the $40 / 40$ standards were phased in over time rather than instituted all at once. Beginning on October 24, 1938, firms engaged in interstate commerce had to pay at least 25 cents per hour and had to pay time and a half on hours beyond 44 hours per week. The minimum wage rose to 30 cents per hour and the maximum workweek (without overtime pay) fell to 42 hours in October 1939. The overtime cutoff fell then fell to 40 hours in October 1940. However, the average work week was still under 37 hours during the period, so the overtime cutoff likely did not have much effect until the end of 1940. Similarly, the minimum average wage was binding only in some industries in the South and Andrew Seltzer (1997) shows that those industries routinely found ways around the law. ${ }^{7}$

\footnotetext{
${ }^{7}$ Another significant change was the introduction of unemployment insurance. The impact of this change is not easily seen in aggregate data because many states delayed in passing the enabling legislation and 20 states did not begin paying claims until 1939.
} 


\section{Conclusions}

One of the most serious problems for the current economy is the sharp drop in total hours worked since the financial crisis of 2007-2008. Total hours can change due to changes in employment or in hours worked per worker. Comparisons for manufacturing over the past century show that the contribution of changes in weekly hours to changes in total hours worked has changed enormously. During the 2000s when hours of work increased, increases in weekly hours accounted for an all-time high of nearly two-thirds of the change in total hours. During declines in total hours, less than 15 percent of the decline came in the form of drops in weekly hours with the balance attributable to layoffs. The pattern is quite different from other decades and particularly, the Great Depression of the 1930s, when roughly half of changes in total hours were contributed by changes in weekly hours.

One reason for the differences between the 1930s, the 2000s, and other decades is the structure of federal policy toward labor during the 1930s. Both the Hoover and Roosevelt Administrations actively pressed industry to adopt a job-sharing employment packages that combined lower hours per week with maintained hourly wages, so that more workers could be employed. The policies changed several times and most of the changes led to different contributions of changes in weekly hours to changes in total hours worked. Hoover's jawboning in the early 1930s led to substantial changes when compared with the 1920s. The most powerful effects were found under Roosevelt's President'sRe-employment Agreements in the second half of 1933, which appear to have had powerful effects that reduced weekly hours and raised wage rates, while sharply increasing job-sharing. Once the National Labor Relations Act was affirmed by the Supreme Court, weekly hours again fell sharply and wage rates rose, setting the stage for the patterns seen in the 1950s, 1960s, and 1970s. 
This paper focuses on the aggregate information for manufacturing to tell the story. It summarizes the experiences we have found for most manufacturing industries during the 1930s. The PRA effects in manufacturing look similar for trade, and mining and miscellaneous categories, but are not there for utilities, which had different labor market institutions. Furthermore, some sectors like mining and railroads were governed by policies specific to those sectors. Preliminary work shows that the size of the effects of the job sharing in the raw data still are present after controlling for cycles, seasonality, and policies directed at the money supply, deficit, and relief. 
Table 1

Median WHS and Average Workweek During Decades, 1920s-1930s and 1950s-2000s

\begin{tabular}{|c|c|c|c|c|c|c|c|c|}
\hline & \multicolumn{8}{|c|}{ Decade } \\
\hline Measure & $1920 \mathrm{~s}$ & $1930 \mathrm{~s}$ & $1950 \mathrm{~s}$ & $1960 \mathrm{~s}$ & 1970s & $1980 \mathrm{~s}$ & $1990 \mathrm{~s}$ & $2000+$ \\
\hline Median WHS During Decade & $35 \%$ & $48 \%$ & $30 \%$ & $33 \%$ & $27 \%$ & $32 \%$ & $33 \%$ & $40 \%$ \\
\hline Median WHS During Upswings & $32 \%$ & $45 \%$ & $26 \%$ & $23 \%$ & $23 \%$ & $38 \%$ & $46 \%$ & $64 \%$ \\
\hline $\begin{array}{l}\text { Median WHS During } \\
\text { Downswings }\end{array}$ & $38 \%$ & $51 \%$ & $33 \%$ & $43 \%$ & $31 \%$ & $27 \%$ & $20 \%$ & $15 \%$ \\
\hline Difference & $6 \%$ & $6 \%$ & $7 \%$ & $19 \%$ & $8 \%$ & $-12 \%$ & $-26 \%$ & $-49 \%$ \\
\hline Average Work Week & 47.9 & 37.7 & 40.3 & 40.6 & 40.1 & 40.3 & 41.2 & 40.8 \\
\hline
\end{tabular}

Sources: Data are for all manufacturing industries. For 1920-1940 source is “Average Hours of Work per Week, Manufacturing Industries, Total Wage Earners," National Industrial Conference Board. Data for 1950 through 2011 are from Bureau of Labor Statistics establishment surveys. [Add precise sources.] See online appendix for methods of calculation. 


\section{Table 2}

Median WSH and Average Weekly Hours Under Different Policy Regimes, 1920-1940

\begin{tabular}{|c|c|c|c|c|c|c|c|c|}
\hline \multirow[b]{2}{*}{ Measure } & \multicolumn{8}{|c|}{ Policy Regime } \\
\hline & $\begin{array}{c}1920- \\
\text { Oct. } 1929 \\
\end{array}$ & $\begin{array}{c}\text { Nov. } \\
1929- \\
\text { Oct. } 1930\end{array}$ & $\begin{array}{l}\text { Nov. } \\
1930 \text { - } \\
\text { Aug. } \\
1932\end{array}$ & $\begin{array}{c}\text { Sept. } \\
1932 \text { - } \\
\text { Jul. } 1933\end{array}$ & $\begin{array}{c}\text { Aug. } \\
1933 \text { - } \\
\text { Dec. } \\
1933\end{array}$ & $\begin{array}{c}\text { Jan. } 1934 \\
\text { - May } \\
1935 \\
\end{array}$ & $\begin{array}{c}\text { Jun. } 1935 \\
\text { - Apr. } \\
1937 \\
\end{array}$ & $\begin{array}{c}\text { May } 1937 \\
\text { - Dec. } \\
1940\end{array}$ \\
\hline Median WSH for Period & $34 \%$ & $54 \%$ & $66 \%$ & $60 \%$ & $33 \%$ & $42 \%$ & $46 \%$ & $45 \%$ \\
\hline Median WSH During Upswings & $32 \%$ & $65 \%$ & $80 \%$ & $49 \%$ & $-23 \%$ & $41 \%$ & $42 \%$ & $40 \%$ \\
\hline $\begin{array}{l}\text { Median WSH During } \\
\text { Downswings }\end{array}$ & $36 \%$ & $43 \%$ & $52 \%$ & $71 \%$ & $89 \%$ & $43 \%$ & $49 \%$ & $49 \%$ \\
\hline $\begin{array}{l}\text { Difference in WSH Between } \\
\text { Upswings and Downswings }\end{array}$ & $4 \%$ & $-23 \%$ & $-28 \%$ & $22 \%$ & $112 \%$ & $2 \%$ & $6 \%$ & $9 \%$ \\
\hline Average Weekly Hours & 48.2 & 45.6 & 40.5 & 38.6 & 36.6 & 35.7 & 38.7 & 36.6 \\
\hline
\end{tabular}

Source: Data are from National Industrial Conference Board . “Average Hours of Work per Week, Manufacturing Industries, Total Wage Earners." See online appendix for methods of calculation. The industries are automobiles, boots and shoes, chemicals, leather goods, machinery, meat packing, paper and pulp, silk/rayon, pig iron, rubber, and wool. 
Figure 1

Monthly Indices (1929=100) for Industrial Production and Total Labor Hours, Average Weekly Hours, and Real Average Hourly Earnings in Manufacturing, January 1930 to December 1940

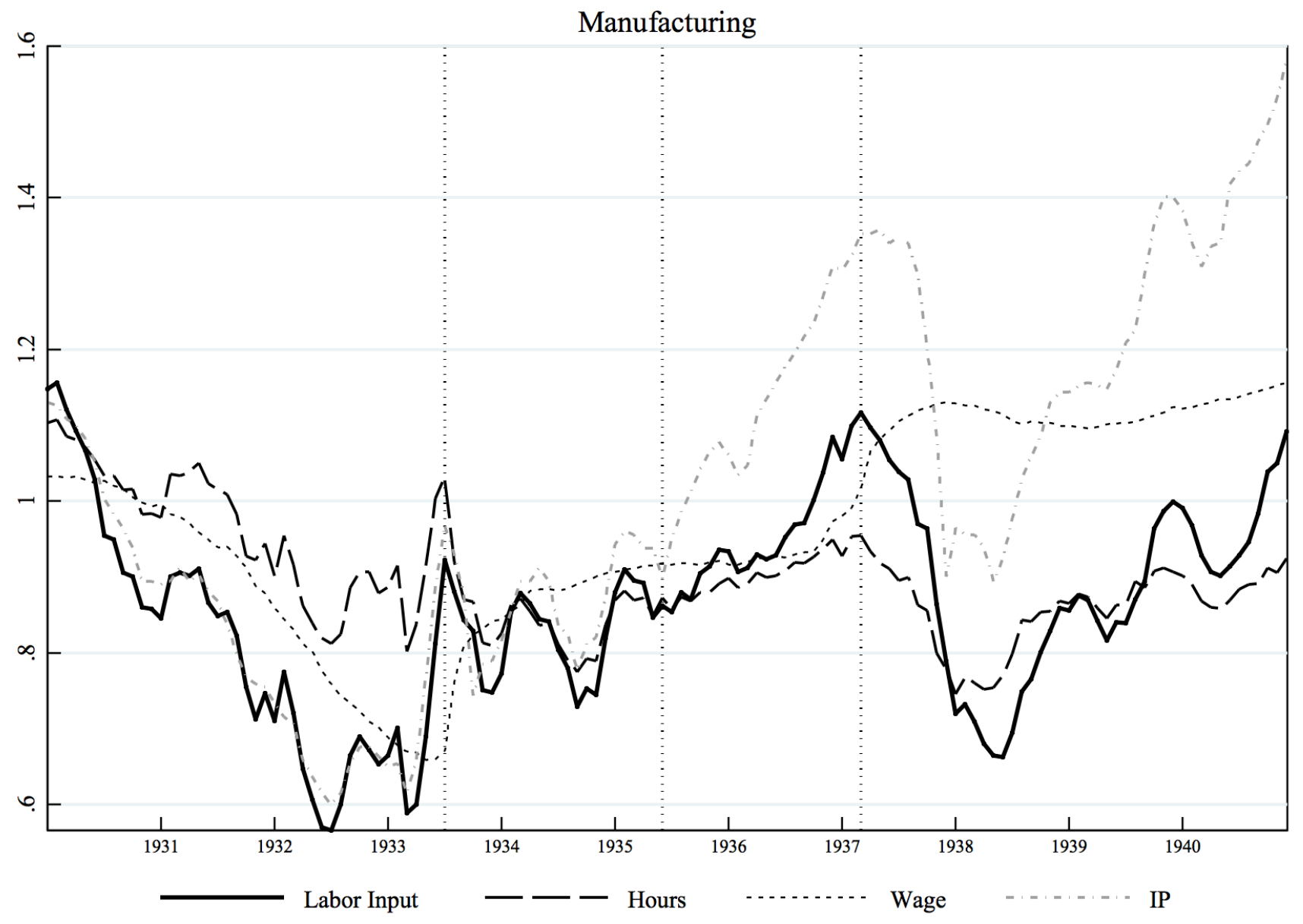

Source: National Industrial Conference Board. 


\section{On-Line Appendix}

\section{Calculating the Weekly Hours Share Measure for a Time Period}

To provide a sense of how changes in weekly hours contributed to changes in total hours worked during a week in different policy regimes during the 1930s in Table ??, we collected data from surveys of establishments from the National Industrial Conference Board (NICB) in the 1920s and 1930s for 11 industries between 1920 and 1940. For comparisons across the decades in Table 1 we used the data aggregated for all manufacturing from the NICB from 1920 to 1940 and the data aggregated for all manufacturing collected from the establishment surveys by the Bureau of Labor Statistics from 1950 through 2011.

Total hours worked during the week in industry $i$ in month $t\left(\mathrm{H}_{\mathrm{it}}\right)$ is the product of average hours per week in industry $i$ in month $t$ weekly hours $\left(\mathrm{h}_{\mathrm{it}}\right)$ and average employment in the week closest to the $15^{\text {th }}$ of month $t$ in industry $i\left(E_{i t}\right)$.

$\mathrm{H}_{\mathrm{it}}=\mathrm{h}_{\mathrm{it}} * \mathrm{E}_{\mathrm{it}}$

The natural log of the equation is

$\ln \left(\mathrm{H}_{\mathrm{it}}\right)=\ln \left(\mathrm{h}_{\mathrm{it}}\right)+\ln \left(\mathrm{E}_{\mathrm{it}}\right)$.

To smooth the data some for sharp changes that might have occurred due to unusual fluctuations, we calculate growth rates over a three month period can be calculated as

$$
\ln \left(\mathrm{H}_{\mathrm{it}}\right)-\ln \left(\mathrm{H}_{\mathrm{it}-3}\right)=\left[\ln \left(\mathrm{h}_{\mathrm{it}}\right)-\ln \left(\mathrm{h}_{\mathrm{it}-3}\right)\right]+\left[\ln \left(\mathrm{E}_{\mathrm{it}}\right)-\ln \left(\mathrm{E}_{\mathrm{it}-3}\right)\right]
$$

Note that this will lead to overlaps across periods. The share of the contribution of the log change in weekly hours to the log change in total hours, which we call Weekly Hours Share (WHS)

$$
\mathrm{WHS}_{\mathrm{it}, \mathrm{t}-3}=\left[\ln \left(\mathrm{h}_{\mathrm{it}}\right)-\ln \left(\mathrm{h}_{\mathrm{it}-3}\right)\right] /\left[\ln \left(\mathrm{H}_{\mathrm{it}}\right)-\ln \left(\mathrm{H}_{\mathrm{it}-3}\right)\right] * 100 \text {. }
$$


To see how the contribution varied between one policy regime $(p)$ and the next during upswings in total hours worked $(U)$, we calculated the median WHS during Hours Share for industry-months during upswings

$$
\mathrm{WHS}_{\mathrm{p}}^{\mathrm{U}}=\operatorname{Median}\left(\mathrm{HS}_{\mathrm{it}}\right) \mid\left[\ln \left(\mathrm{H}_{\mathrm{it}}\right)-\ln \left(\mathrm{H}_{\mathrm{it}-3}\right)\right]>0,
$$

And we made a similar calculation for industry-months during downswings.

$$
\mathrm{WHS}_{\mathrm{p}}^{\mathrm{D}}=\operatorname{Median}\left(\mathrm{HS}_{\mathrm{it}}\right) \mid\left[\ln \left(\mathrm{H}_{\mathrm{it}}\right)-\ln \left(\mathrm{H}_{\mathrm{it}-3}\right)\right]<0,
$$

We used the medians so that highly unusual values did not dominate the measure.

We followed the same procedure for calculating the WHS during upswings and downswings in manufacturing for each decade in Table 1 except that we used the aggregate manufacturing observations rather than industry specific observations, which leads to the removal of the industry $i$ subscript from all of the equations. 


\section{Appendix II}

Figures with Monthly Indices $(1929=100)$ for Industrial Production and Total Labor Hours, Average Weekly Hours, and Real Average Hourly Earnings in Other Sectors, January 1930 to December 1940

Appendix Figure II-1

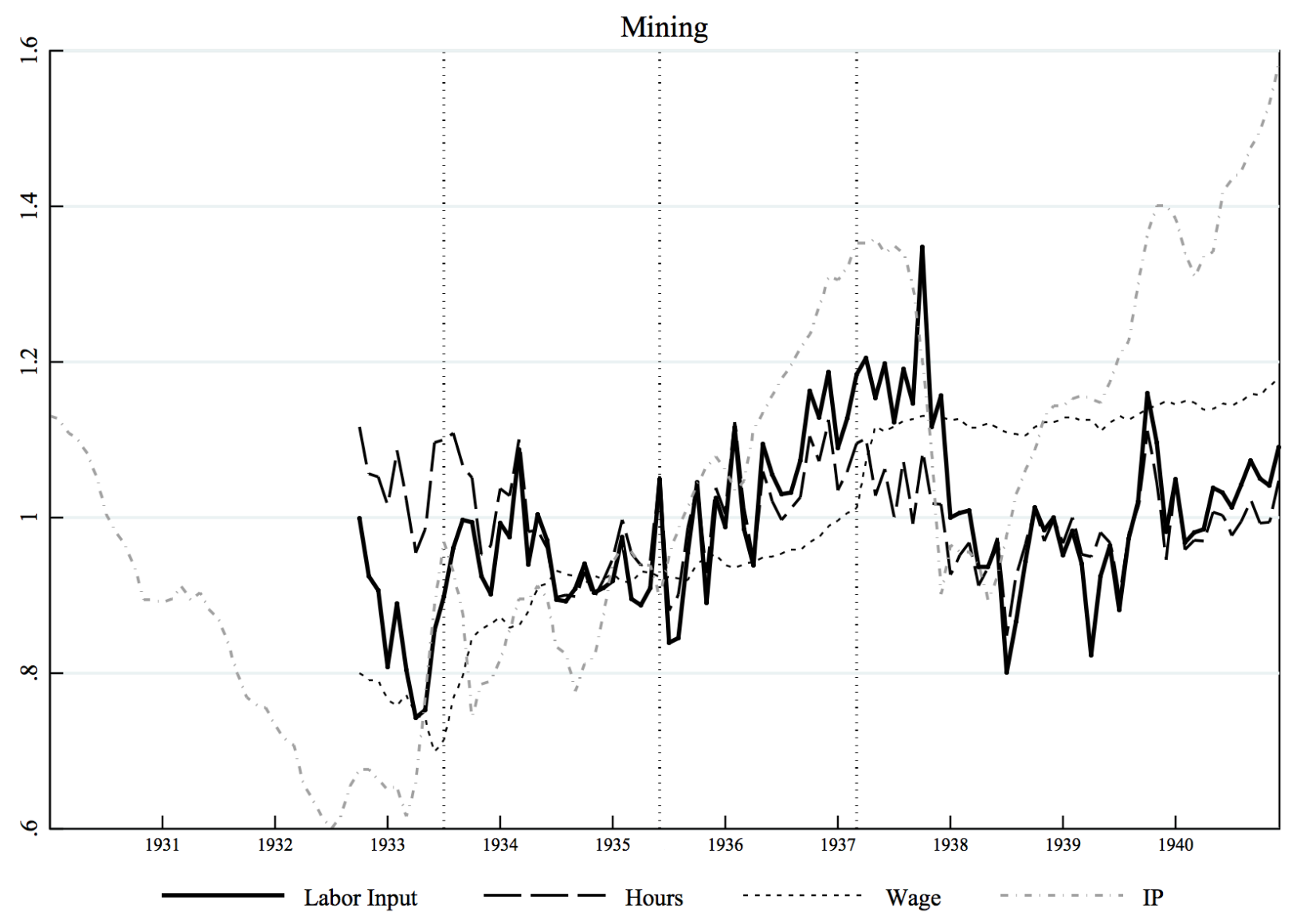


Appendix Figure II-2

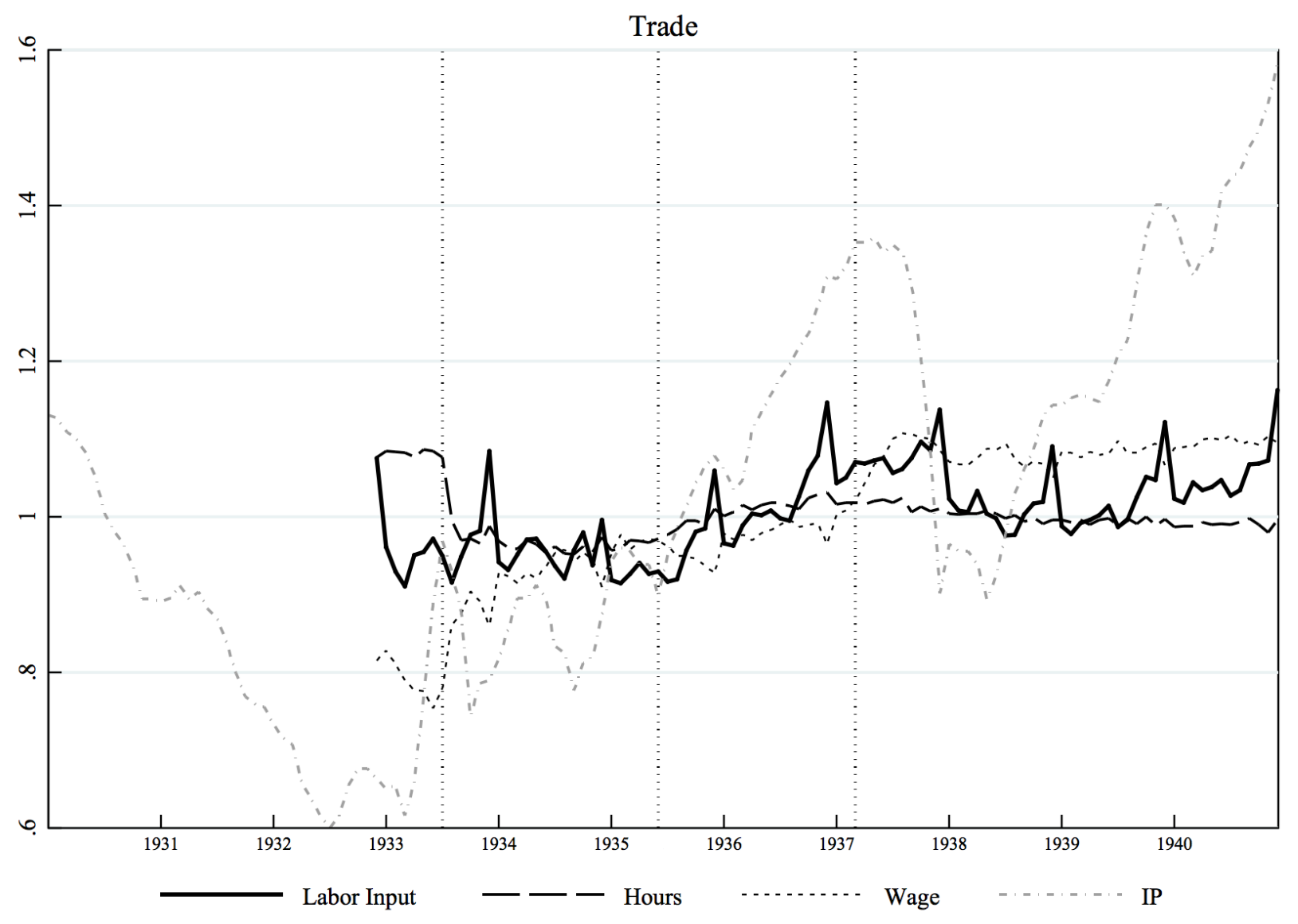


Appendix Figure II-3

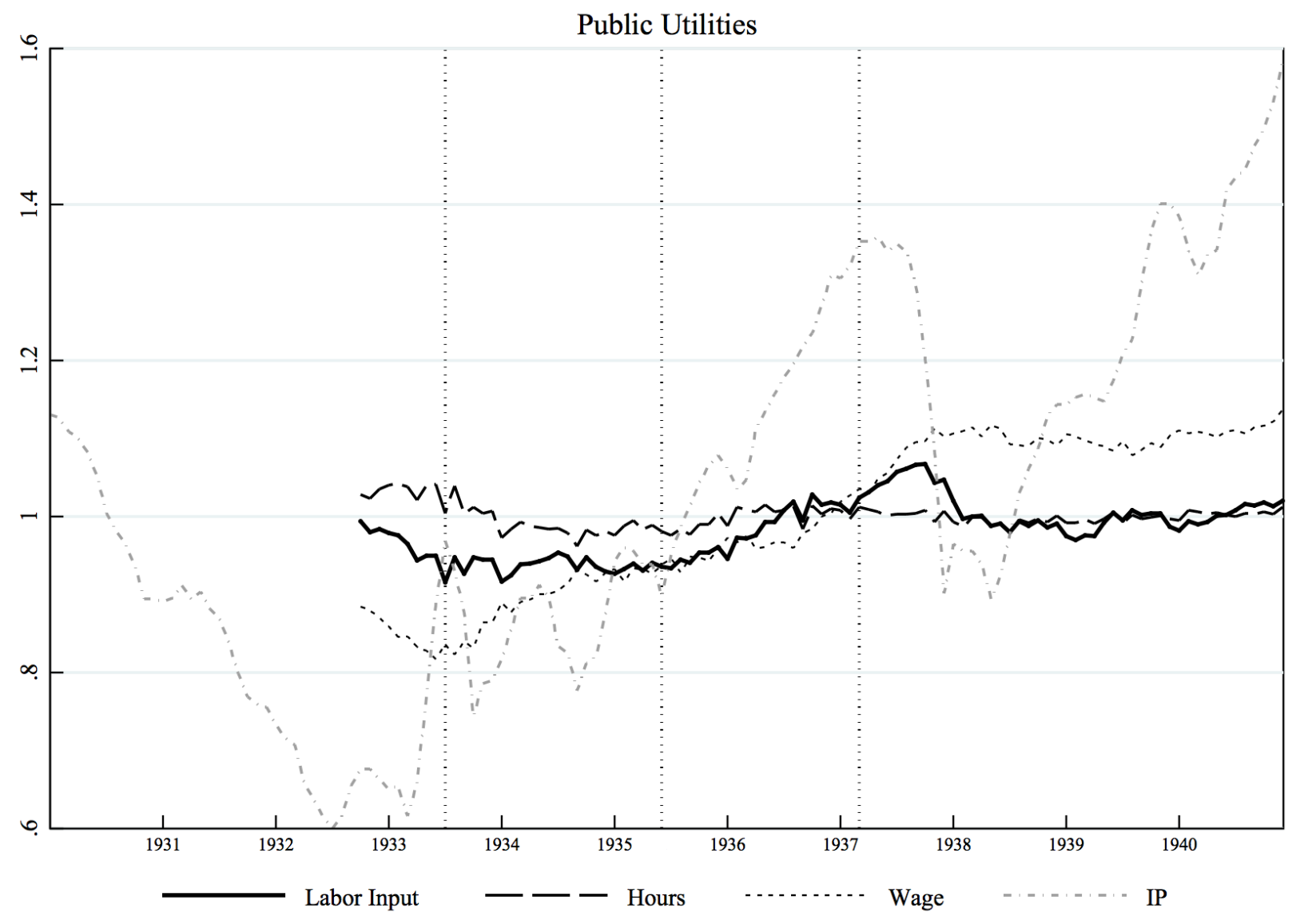




\section{Appendix Figure II-4}

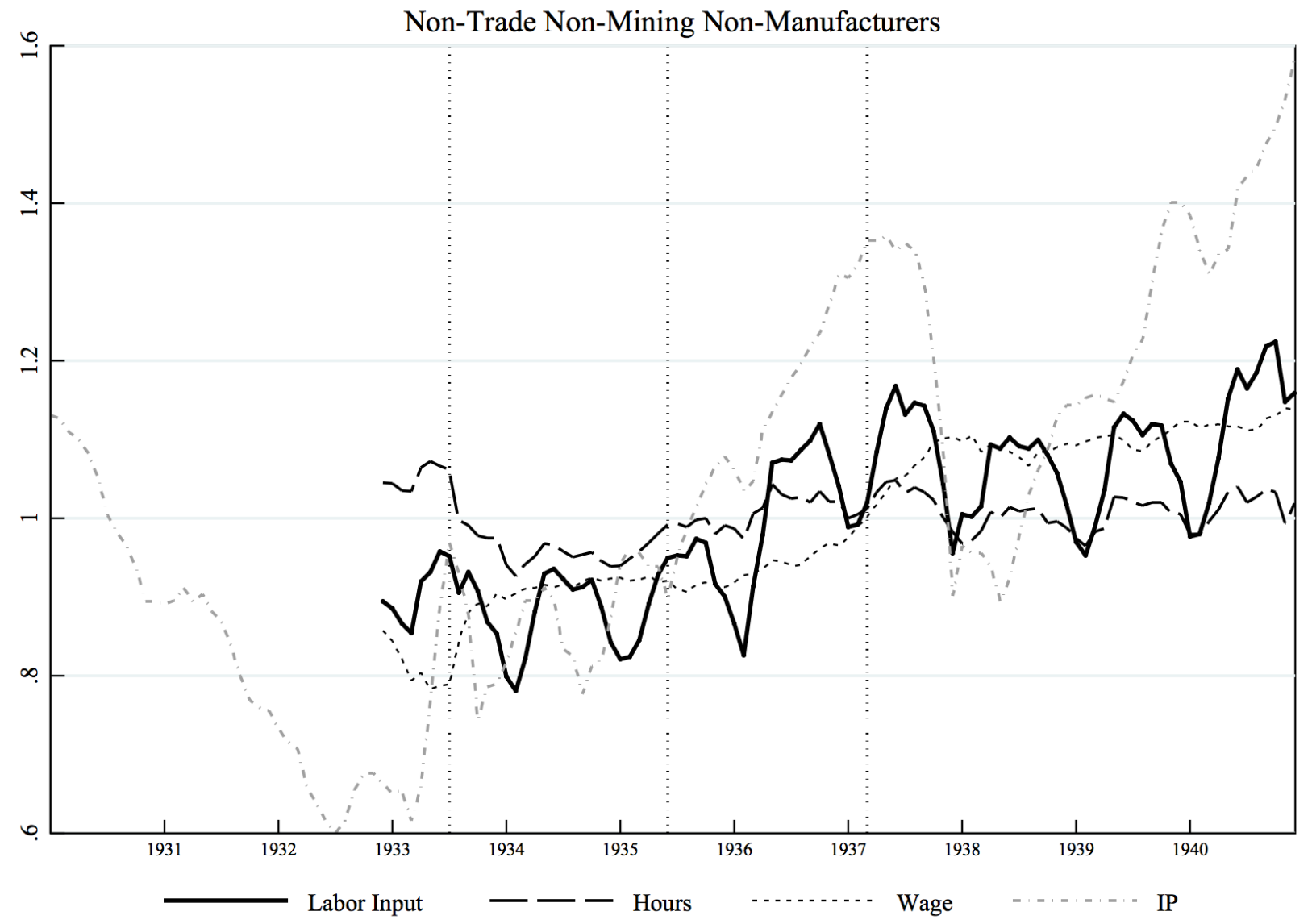




\section{References}

Baily, Martin. 1977. "On the Theory of Layoffs and Unemployment. Econometrica 45 (July): 1043-63.

Bernanke, Benjamin. 1983. "Employment, Hours, and Earnings in the Depression: An Analysis of Eight Manufacturing Industries.” American Economic Review 76 (March): 82-109.

Bernanke, Benjamin and James Powell. 1986. "The Cyclical Behavior of Industrial Labor Markets: A Comparsion of the Prewar and Postwar Eras.” The American Business Cycle: Continuity and Change. Ed. Robert J. Gordon, 583-638. Chicago: University of Chicago Press.

Bernstein, Irving. 2010. The Lean Years: A History of the American Worker, 1920-1933. Chicago: Haymarket Books. First Published 1969 by Houghton Mifflin.

Cole, Harold and Lee Ohanian. 1999. "The Great Depression in the United States from a Neoclassical Perspective." Federal Reserve Bank of Minneapolis Quarterly Review 23 (Winter): 2-24.

. 2004. New Deal Policies and the Persistence of the Great Depression: A General Equilibrium Analysis.” Journal of Political Economy 112 (): 779-816.

Gordon, Robert and Martin Baily. 1993. "Jobless Recovery: Does It Signal a New Era of Productivity-Led Growth? Brookings Papers on Economic Activity 1993: 271-316.

Hanes, Christopher and John James. 2012. "Wage Rigidity in the Great Depression.” Working Paper presented at the NBER-DAE Summer Institute, July.

Himmelberg, R. F. 1993. The Origins of the National Recovery Administration: Business, Government, and the Trade Association Issue, 1921-1933. New York: Fordham University Press. 
Hoover, Herbert. 1953. The Memoirs of Herbert Hoover: The Great Depression 1929-1941. New York: Macmillan.

Hunnicutt, Benjamin Kline. 1996. Kellogg's Six-Hour Day. Philadelphia: Temple University Press.

Koenders, Kathryn and Richard Rogerson. 2005. "Organizational Dynamics Over the Business Cycle: A View on Jobless Recoveries.” Federal Reserve Bank of St. Louis Review 87 (July/August): 555-79.

National Industrial Conference Board. ???Get precise citation????

Rose, Jonathan D. 2010. “Hoover's Truce: Wage Rigidity in the Onset of the Great Depression” Journal of Economic History 70 (December): 843-870.

Rosenbloom, Joshua. "Labor Unions," in Historical Statistics of the United States: Earliest Times to the Present, Millennial Edition, Volume 2: Work and Welfare. Ed. Susan Carter, Scott Sigmund Gartner, Michael Haines, Alan Olmstead, Richard Sutch, and Gavin Wright. New York: Cambridge University Press, 2006, pp. 336-362.

Seltzer, Andrew. 1997. "The Effects of the Fair Labor Standards Act of 1938 on the Southern Seamless Hosiery and Lumber Industries.” Journal of Economic History 57 (June): 396415.

Taylor, Jason E. 2011. "Work-Sharing During the Great Depression: Did the President's Reemployment Agreement Promote Reemployment? Economica 78 (January): 133-158.

Taylor, Jason and P.G. Klein. 2008. "Anatomy of a Cartel: the National Industrial Recovery Act of 1933 and the Compliance Crisis of 1934. Research in Economic History 26: 23571.

U.S. Bureau of Labor Statistics, various months. Monthly Labor Review. 
U.S. Bureau of Labor Statistics. Get Precise citation for the hours data after 1950???

Weinberg, Arthur and Weinberg, Lila. 1968. Passport to Utopia: Great Panaceas in American History. Chicago: Quandrangle Books. 